\title{
Design and simulation of a vertical wind generator
}

\section{Diseño y simulación de un generador eólico vertical}

CHÁVEZ-CANO, Omar†'*, MUÑOZ-HERNÁNDEZ, Germán Ardul, TURIJÁN-ALTAMIRANO, Salomón Noé and RODRÍGUEZ-GONZÁLEZ, Julio

\section{Tecnológico Nacional de Mexico / Instituto Tecnológico de Puebla}

ID $1^{\text {st }}$ Author: Omar, Chávez-Cano / ORC ID: 0000-0002-1883-1932, CVU CONACYT ID: 857314

ID $1^{\text {st }}$ Coauthor: German Ardul, Muñoz-Hernandez / ORC ID: 0000-0003-4861-0345, CVU CONACYT ID: 122490

ID $2^{\text {nd }}$ Coauthor: Salomón Noé, Turiján-Altamirano / ORC ID: 0000-0003-3790-7055, CVU CONACYT ID: 377682

ID $3^{\text {rd }}$ Coauthor: Julio, Rodríguez-González / ORC ID: 0000-0003-0515-778X, CVU CONACYT ID: 78003

\begin{abstract}
The present work describes the design of a Savonius vertical wind generator, low power; To generate electricity for everyday use, which will help the care of the environment. The design is based on the environmental conditions registered at the Technological Institute of Puebla, based on them the materials and components necessary to support the generator were selected, seeking to work efficiently.
\end{abstract}

Savonius, Generator, Wind, Low power

\begin{abstract}
Resumen
El presente trabajo, describe el diseño de un generador eólico vertical tipo Savonius, de baja potencia; para generar energía eléctrica de uso cotidiano, con el cual contribuimos al cuidado del ambiente. El diseño está basado en las condiciones ambientales registradas en el Instituto Tecnológico de Puebla, con base en ellas se seleccionaron los materiales y componentes necesarios para dar soporte al generador, buscando que trabaje de manera eficiente.
\end{abstract}

Savonius, Generador, Viento, Baja potencia

Citation: CHÁVEZ-CANO, Omar, MUÑOZ-HERNÁNDEZ, Germán Ardul, TURIJÁN-ALTAMIRANO, Salomón Noé and RODRÍGUEZ-GONZÁLEZ, Julio. Design and simulation of a vertical wind generator. Journal of Technology and Innovation. 2019, 6-18: 27-33

\footnotetext{
* Correspondence to Author (email: omarchavezkano@gmail.com)

$\dagger$ Investigador contribuyendo como primerAutor.
} 


\section{Introduction}

Until a few centuries ago, humanity covered all its energy demands with solar radiation, the movement of water and wind was used to generate mechanical energy, while wood was an ideal converter of solar energy into storable chemistry, since it gave the heat necessary for homes and other technical applications [1].

According to Lewis, The use of wind generators brings with it some benefits such as: expanding the fields of development and research, increasing technological capabilities and producing less pollution when generating electricity [2].

The Savonius type vertical wind generator was developed in principle by Flettner, using a rotor that is formed from the cut of the cross section of a cylinder, and then rejoined and formed an "S" very similar to the one shown in the Figure 1. [3] [4]

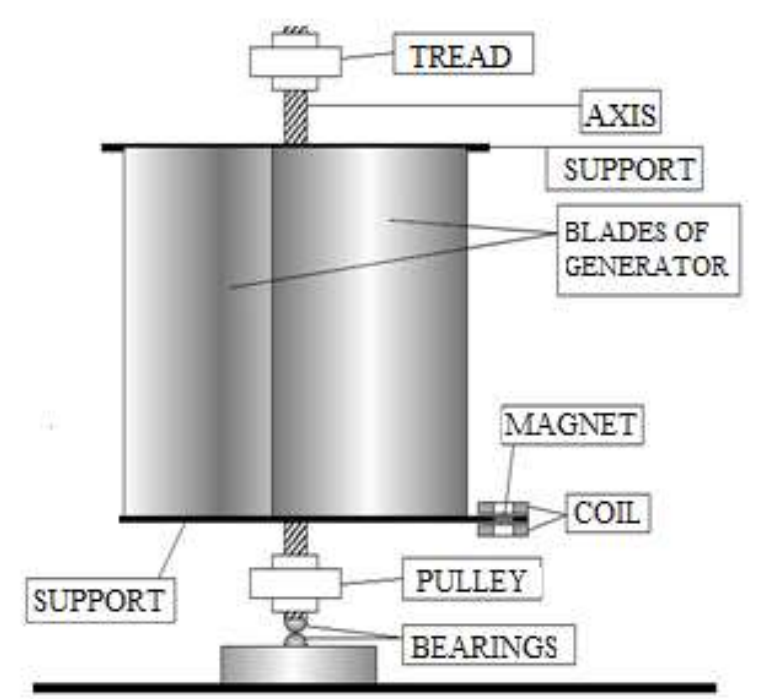

Figure 1 Savonius Generator

The need to take care of the environment has motivated people to look for new ways to generate electricity and with the exponential growth of the population it is important to create devices that work with alternative energies, to continue giving comfort to humanity.

There are many types of generators and many combinations between them, which work smoothly. Some in places with large air flows, but where the wind speed is very low, there are low power generators such as vertical axis.
There are two types:

a) Those of differential drag that take advantage of the difference in wind force between a concave and a convex surface (Savonius).

b) The cyclic incidence variation rotor (Diarreus), as observed in Figure 2.

The development of these mechanisms has been thanks to the research and application of new technologies, together with the selection of new materials, which give us new parameters for their construction and thus increase their efficiency in energy generation.
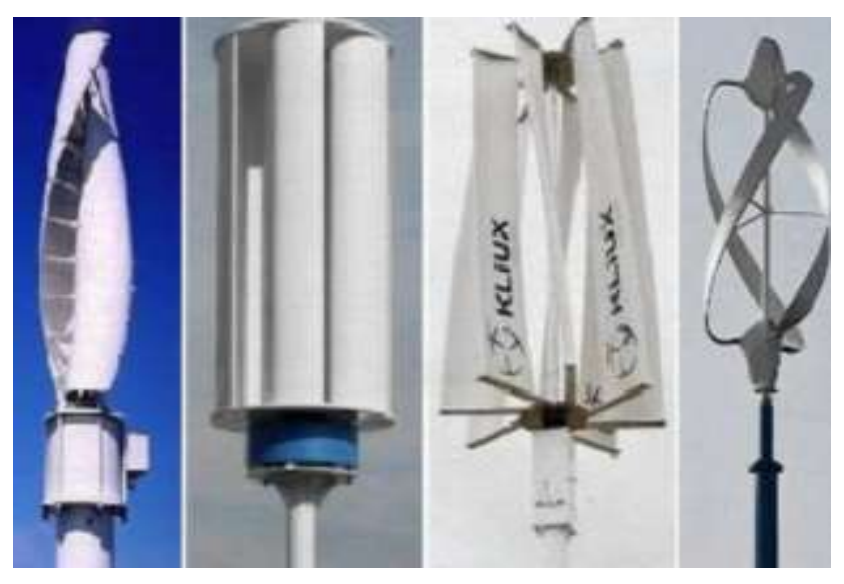

Figure 2 Vertical Generators

Source: Academia.E.Unavarra

\section{Objective of the project}

Design and simulate a low power Savonius wind generator in the flow simulation solidworks 2018 program.

\section{Specific objectives}

Design a savonius type generator capable of operating with a wind speed of $1.2 \mathrm{~m} / \mathrm{s}$ at 2.5 $\mathrm{m} / \mathrm{s}$.

Simulate the Savonius type generator under the climatic conditions of the Technological Institute of Puebla.

\section{Design methodology}

The selection of the vertical wind generator is based on the environmental conditions of the place where it will be installed (Instituto Tecnologico de Puebla), with geographical location of $1^{\circ} 04^{\prime} 11^{\prime \prime} \mathbf{N} 98^{\circ} 10^{\prime} 08^{\prime \prime} \mathrm{O}$, as described below: 
- $\quad$ Average wind speed $2 \mathrm{~m} / \mathrm{s}$

- $\quad$ Altitude 2160 msnm.

- $\quad$ Air density $0.889 \frac{\mathrm{km}}{\mathrm{m}^{3}}$.

- $\quad$ Class roughness 6 (table 2).

- $\quad$ Atmospheric pressure of $1017 \mathrm{hPa}$.

Savonius generators are rare mechanisms, since these are applied where the air currents are low or in places where electrification is sought to exist more easily.

Vertical axis generators present as the most relevant advantages:

a) A vertical symmetry, so they do not require guidance systems.

b) They have better accessibility, so maintenance tasks are facilitated.

c) They do not require start-up and step change mechanisms [1][6]

The average air speed is very low, as indicated by the Beutherford scale [5] in Table 1 and also because there is a lot of roughness in the environment, it is very difficult for the wind to circulate freely.

\begin{tabular}{|l|l|l|l|}
\hline Degrees & $\mathbf{V}(\mathbf{k m} / \mathbf{h})$ & $\mathbf{V}(\mathbf{m} / \mathbf{s})$ & \multicolumn{1}{|c|}{ Description } \\
\hline 0 & 1 & $0.0-0.4$ & Calm \\
\hline 1 & $1-5$ & $0.5-1.5$ & Very light wind \\
\hline 2 & $6-11$ & $1.3-3.4$ & Wind light \\
\hline 3 & $12-19$ & $3.5-5.5$ & Breeze \\
\hline 4 & $20-28$ & $5.5-8.0$ & Moderate \\
\hline 5 & $29-38$ & $8.1-10.9$ & Fresh wind \\
\hline
\end{tabular}

Table 1 Beutherford scale

According to the information obtained through the anemometer, used to collect the data, it follows that: the average of the minimum annual speed is $5.6 \mathrm{~km} / \mathrm{h}$ and the annual maximum of $9 \mathrm{~km} \mathrm{/} \mathrm{h}$ as shown in Figure 3, which indicates the behavior of wind speed.

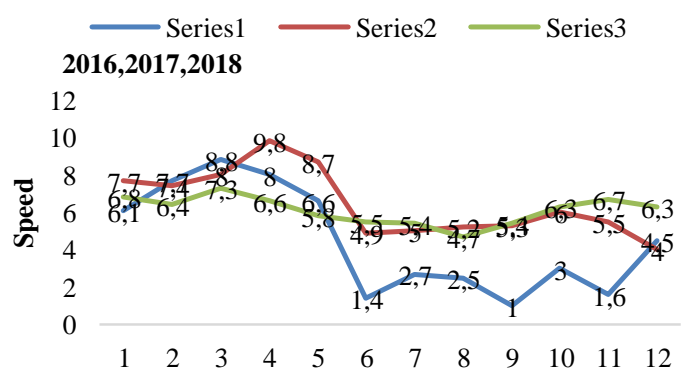

Figure 3 Speed chart
The power coefficient relates the extracted power and the total wind power. By Betz's Law, it is impossible for a machine to extract all the power of the wind. In this way, the power extracted by the wind turbine will depend on its power coefficient, which in turn depends largely on the shape of the blades.

Betz's Law postulates:

"Only less than 16/27 of the kinetic energy of the wind can be converted into mechanics using a wind turbine, approximately $59 \%$.

Theoretically, not many equations have been developed that relate the power coefficient to the characteristics of the Savonius rotor. [7]

Experimentally, curves have been constructed where they explain the power coefficient as a function of the speed of the different air generators (Figure 4), which relate the power coefficient to the blade tip speed; where it has been found that the maximum power coefficient of a Savonius rotor reaches the value of 0.33 . [5]

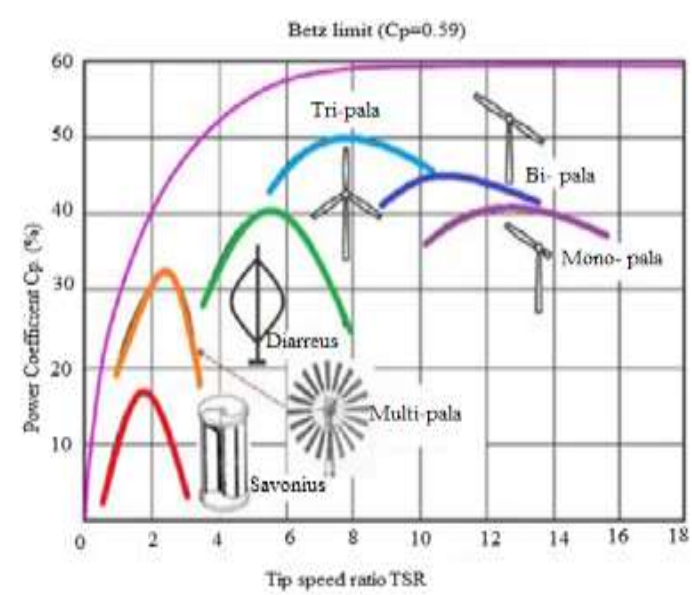

Figure 4 Power coefficient

Source: Villarubia Wind Engineering

In Figure 5, it is observed how the wind hits the place where we will place the wind generator, coupled with it, the direction in which the wind moves, which is from south to west, is indicated. 


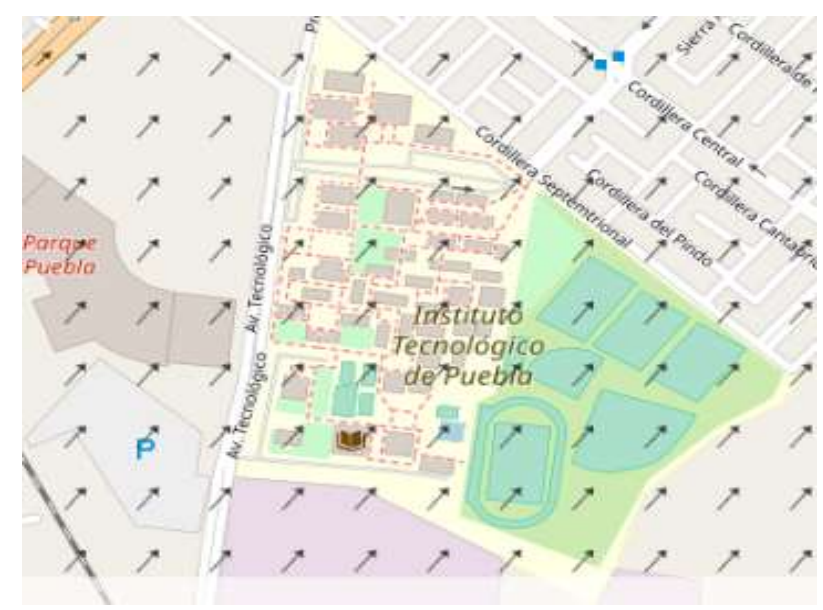

Figure 5 Speeds gradient

The data obtained in Figure 3 indicate the wind behavior, but in Figure 6 we observe the wind rose, which tells us how the wind moves and in which direction, although to us by the Savonius type generator that we select, it is indifferent since these types of generators work in any wind direction.

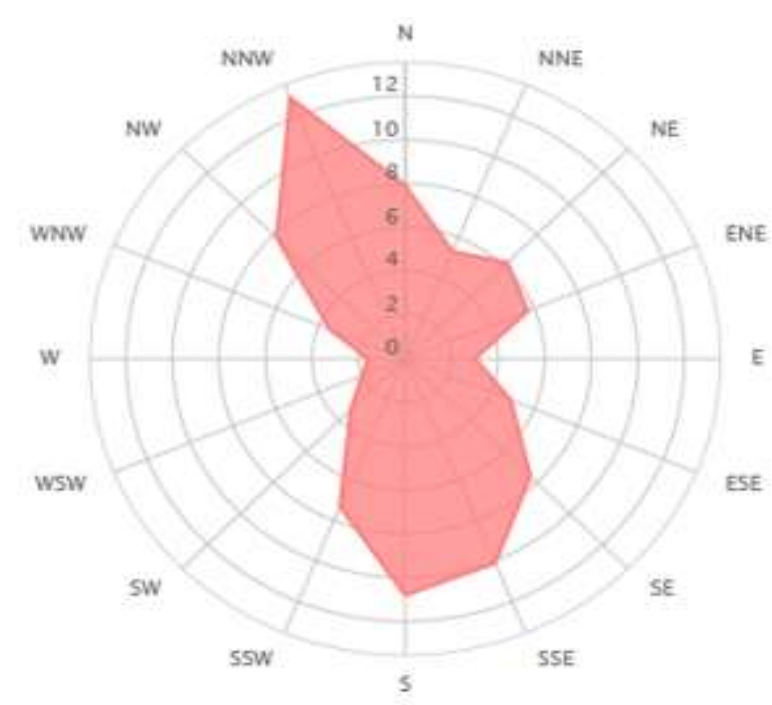

Figure 6 Wind distribution in the area of the Technological Institute of Puebla

It is important to define some parameters before starting the design of the wind turbine, which serve to take into account some structural and geometric characteristics, such as: the bearings, the arrow of the model to be designed, as well as the environment in which the wind machine will be installed; as seen in Table 2, which describes the roughness.

\begin{tabular}{|l|l|l|}
\hline Class & \multicolumn{1}{|c|}{ M } & \multicolumn{1}{|c|}{ Description } \\
\hline 1 & 0.0009 & Water free surface \\
\hline 2 & 0.005 & $\begin{array}{l}\text { Naked soil or with very little } \\
\text { vegetation(.30m) }\end{array}$ \\
\hline 3 & 0.05 & $\begin{array}{l}\text { Soil covered with vegetation (2m),or } \\
\text { naked floor }\end{array}$ \\
\hline 4 & 0.4 & Low building \\
\hline 5 & 0.8 & $\begin{array}{l}\text { Alborea vegetation with heights over } \\
\text { 4m. }\end{array}$ \\
\hline 6 & 1.0 & High building \\
\hline
\end{tabular}

Table 2 Roughness of the environment

With the information collected, both from the environment and the power coefficient, we can design the Savonius generator. Considering the necessary data to calculate its dimensions shown in Figure 7, which generated the following data for its design:
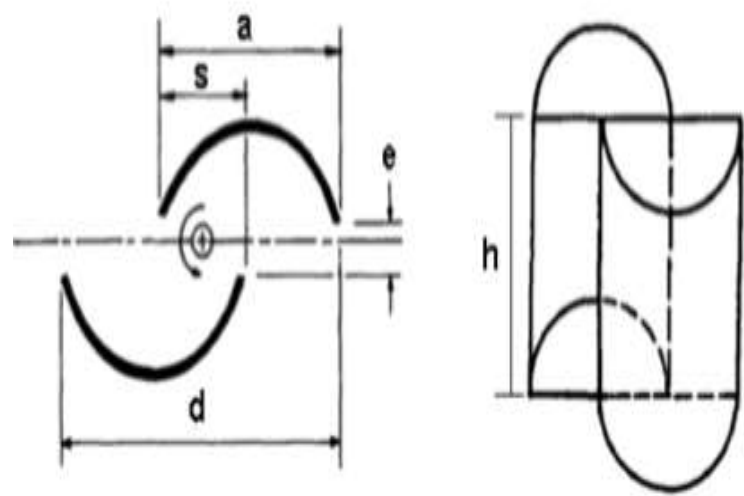

Figure 7 Savonius Generator, dimensions of blades

Generator Dimensions:

Speed: $2.5 \mathrm{~m} / \mathrm{s}$

Air density $0.889 \frac{\mathrm{km}}{\mathrm{m}^{3}}$

Sweep area $: 0.50 \mathrm{~m}$

$\mathrm{d}: 0.50 \mathrm{~m}$

$\mathrm{h}: 1 \mathrm{~m}$

e: $0 \mathrm{~m}$

$\mathrm{s}: 0.075 \mathrm{~m}$

\section{Total power extracted}

The amount of wind energy that can transform an equipment into electricity, depends mainly on the wind speed at the site where the generator will be installed

For different reasons, as already mentioned above, it becomes difficult to extract all the kinetic energy existing in an air stream. The power that the system threw at us, taking the characteristics of the place are: 
$P e=h_{n} h_{e}\left(c_{p}\left(\frac{1}{2} \rho \mathrm{A} v^{3}\right)=0.472 \mathrm{w}\right.$

The resultant rotation speed:

$\mathrm{W}=\frac{T S R . v}{r}=8 \frac{r a d}{s}$

And the system revolutions with the calculated speed is:

$\mathrm{N}=\frac{60 . w}{2 \pi}=76.4 \mathrm{rpm}$

Wind turbines that have a smaller blade tip speed are the ones with the highest torque values.

This makes them more recommended for applications that require a high initial torque, such as pumping systems or power generation. is:

The torque delivered to us by the system

$\mathrm{T}=\frac{\mathrm{Pe}}{\mathrm{w}}=.059 \mathrm{Nm}$

The force of the wind that was calculated was:

$\mathrm{Pv}=\rho \frac{\mathrm{v}^{2}}{2}=2.7 \mathrm{~Pa}$

\section{Generator material}

The selected material meets the necessary characteristics to withstand the climatic conditions of the place, in addition to being resistant, light, economic and commercial. This material is shown in Table 3.

\begin{tabular}{|l|l|l|l|l|}
\hline Materials & \multicolumn{1}{|c|}{ Weigth } & Thickness & Blade size & Cost \\
\hline Stainless & $2.6 \mathrm{~kg} / \mathrm{m}^{2}$ & $0.3 \mathrm{~mm}$ & $1.22 \times 3.05 \mathrm{~m}$ & 6500 \\
\hline $\begin{array}{l}\text { Galvanized } \\
\text { sheet }\end{array}$ & -------------- & $.5 \mathrm{~mm}$ & $0.91 \times 4.27 \mathrm{~m}$ & 1800 \\
\hline Acrylic & -------------- & $0.3 \mathrm{~mm}$ & $0.60 \times 120 \mathrm{~m}$ & 1500 \\
\hline $\begin{array}{l}\text { Carbon } \\
\text { fiber }\end{array}$ & ------------- & $.5 \mathrm{~mm}$ & $0.30 \times 0.50 \mathrm{~m}$ & 7000 \\
\hline
\end{tabular}

Table 3 Materials Matrix

The best option for characteristics of weight and workability was the acrylic with a thickness of $0.3 \mathrm{~mm}$, because it has: b) Chemical reactivity It is inert in contact with water, alkalis, aliphatic hydrocarbons and simple esters.

c) The selection of the materials of the structure was a half-inch square PTR square tube of steel to help withstand the force of winds and weather conditions, as seen in Figure 8.

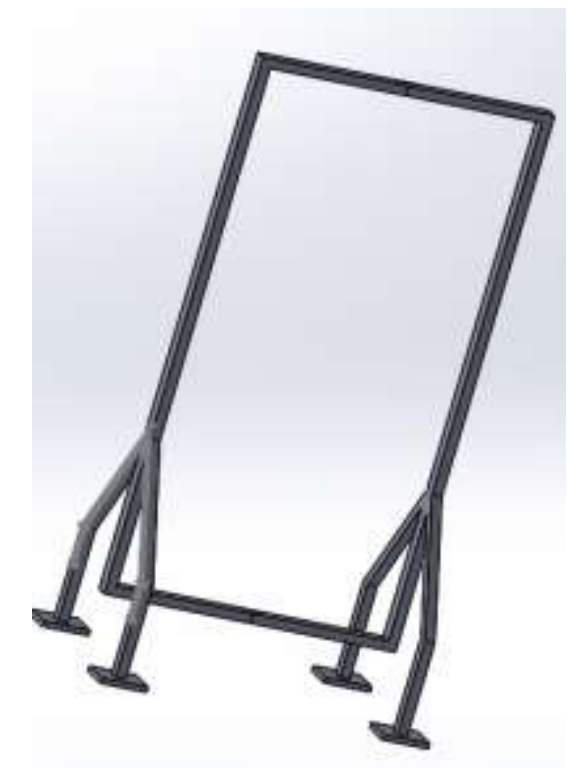

Figure 8 Tubular structure

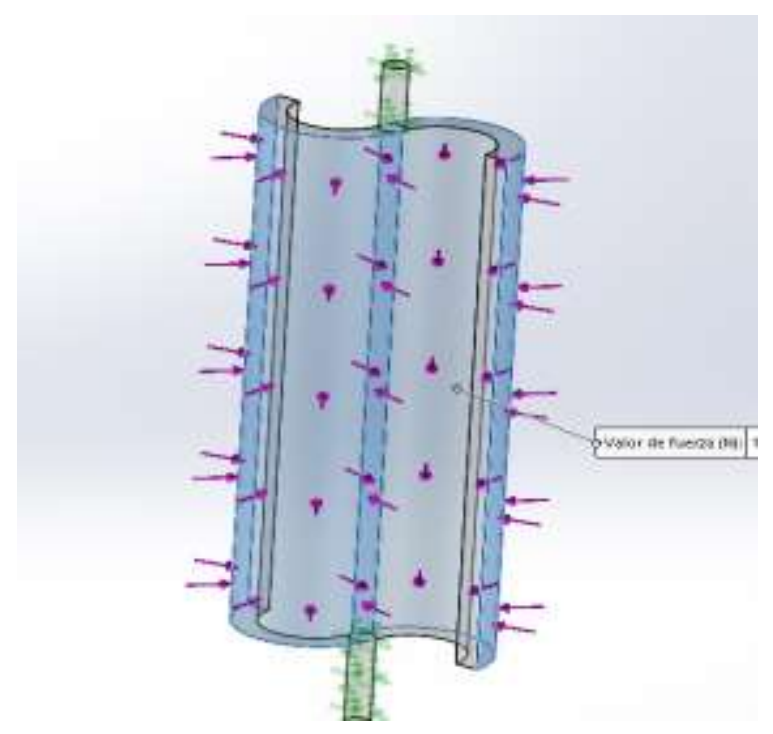

Figure 9 Total assembly

The generator design was built in solidWorks software where it was made part by part until assembled as shown in Figure 9. 


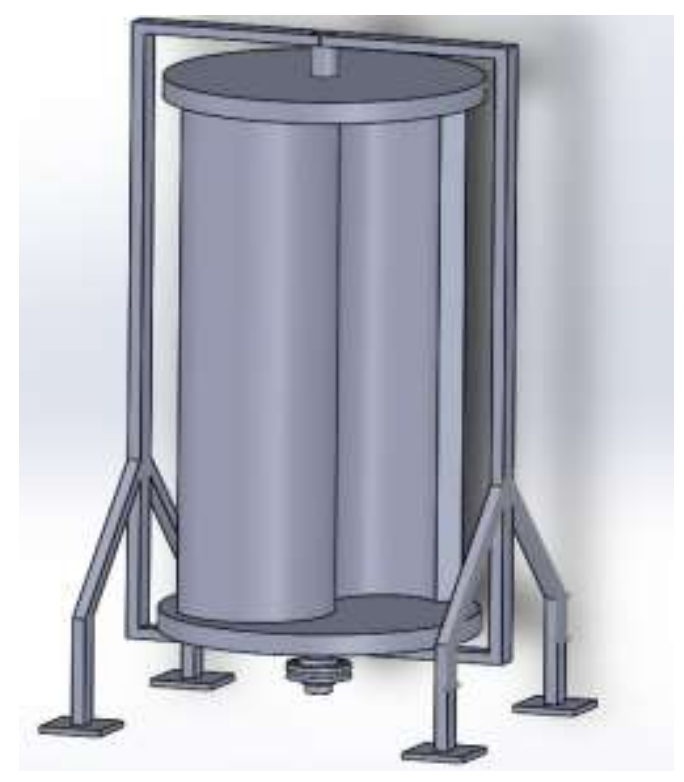

Figure 10 Arrow efforts

\section{Mechanical simulation}

To observe the efforts of the material due to the force of the wind, we used the simulation tool in SolidWorks that facilitated the identification of the contact points, as in the arrow that holds the blades together, which is half an inch aluminum to help the mechanism not to drag more weight, as seen in Figure 10. [7]

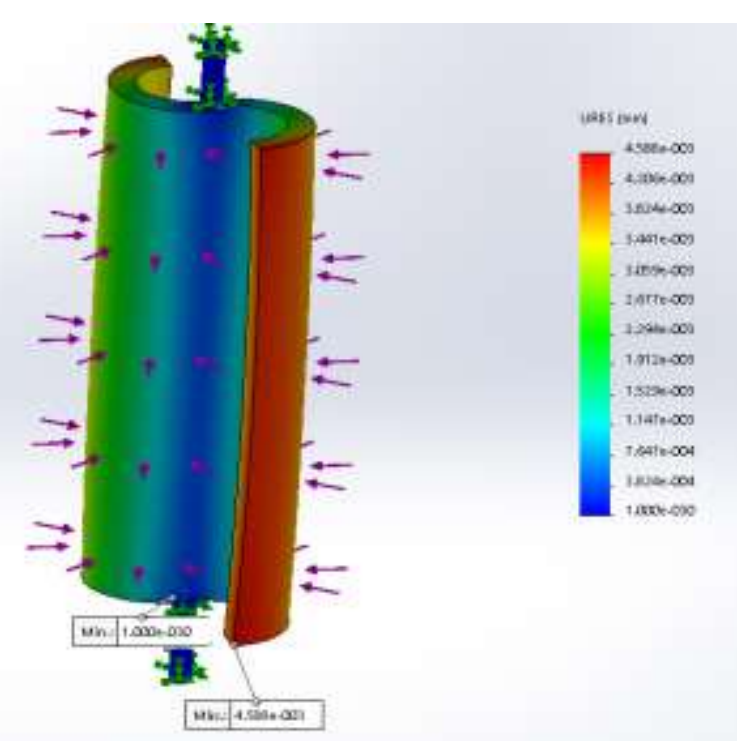

Figure 11 Material effort

Figure 11 shows the complete simulation with the wind force of $2.7 \mathrm{~Pa}$ on the Savonius generator passing through the blades, where the red part indicates that the greatest effort to which the savonius generator will be subjected is $4.500 \times 10^{-3} \mathrm{~N} / \mathrm{m}$.

Minimal effort is $1.00 \times 10^{-3} \mathrm{~N} / \mathrm{m}$, considering the material that is $3 \mathrm{~mm}$ thick acrylic and the dimensions previously obtained.
The simulation is carried out in Solidworks using the flow simulation tool in order to observe the behavior of the system affected by the air flow, which collides with the generator blades where the turbulence is shown (Figure 12).[9]

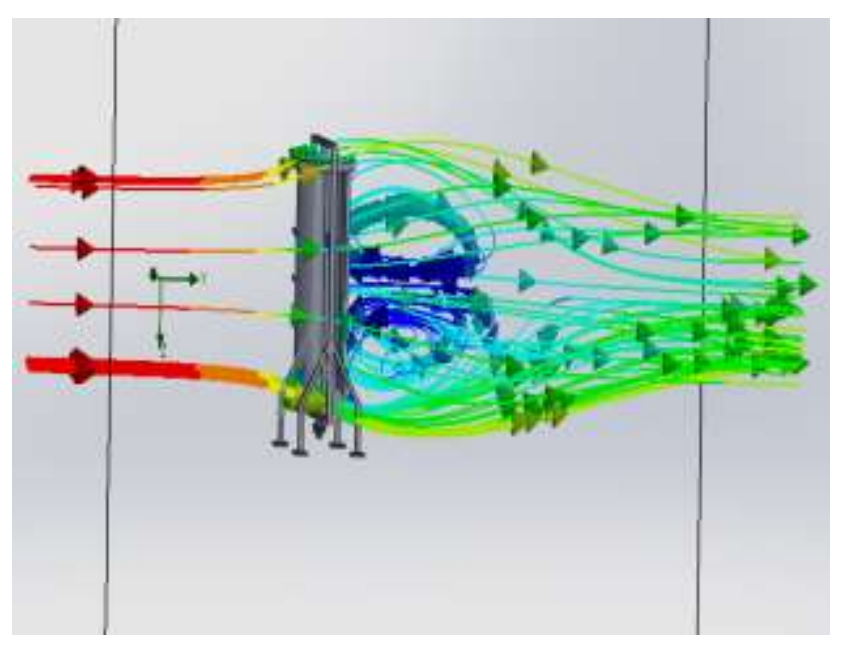

Figure 12 Turbulence simulation

\section{Conclusions}

The design of the Savonius vertical wind generator, gives us a mechanical power of 0.47 $\mathrm{W}$ with dimensions of $0.50 \mathrm{~m}$ wide by $1.00 \mathrm{~m}$ high; with these characteristics it is important to select a good material to face the climatic conditions of the place.

If the generator were placed in a higher place and with less roughness, this would give us more power and in turn would have more effort with respect to the air.

Both in the design and in the selection of the material it is important to understand that the air speed is very low, so that said material will have to be as light as possible, to help the system, making it have the least possible drag.

When increasing the power of the Savonius wind generator, a larger sweeping area would have to be managed, therefore the dimensions of the generator should be proportionally increased; as well as the design parameters.

When doing the simulations in the software, this shows us how the generator would behave with real work, with which we can take new ideas to build the prototype in the future. 


\section{Acknowledgments}

The authors thank the Division of Postgraduate Studies and Research of the Technological Institute of Puebla / Technological National of Mexico, for their collaboration and provision of laboratories and equipment for the development of research and the National Council of Science and Technology for financial support provided.

\section{Referencias}

[1] M. F. Voneschen2, Introducción a la teoría de las turbinas eólicas1.

[2] F. S. veronica, «generador ALISIO,» Revista de ingenieria Innovativa, pp. 41-47, 2017.

[3] M. I. T. K. N. H. M. Hassan, «CFD Analysis of a Twisted Savonius Turbine,» Memorial University of Newfoundland , 2017.

[4] T. L. Y. a. H. Y.] HAYASHI, «Wind Tunnel Tests on a Different Phase ThreeStage Savonius Rotor. J,» JSME International, pp. 916, 2005.

\section{[5] VILLARUBIA,} EOLICA, ALFAOMEG.

[6] M. V. Lopez, Ingenieria de la energia eolica, Barcelona España: MARCOMBO, 2012.

[7] f. R. Arthz, «DISEÑO DE UNA TURBINA EOLICA DE BAJA POTENCIA ADECUADA ALA AGRESIVIDAD DEL CLIMA PATAGONICO,» HYFUSEN, $n^{\circ} 10$ 005, 2011.

[8] C. B. L. VINICIO, «DISEÑO Y CONTRUCCION DE UN GENERADOR EOLICO DE EJE VERTICAL SAVONIUS,» 2016.

[9] S. G. González, El gran libro de SolidWorks, Alfa Omega. 